кандидат педагогічних наук, доцент

(Національна академія сухопутних військ імені Петра Сагайдачного, м. Львів) olegboyko69@gmail.com

ORCID: 0000-0003-3128-300X

\title{
ПЕДАГОГІЧНІ УМОВИ ВПРОВАДЖЕННЯ У НАВЧАЛЬНО-ВИХОВНИЙ ПРОЦЕС ВИЩИХ ВІЙСЬКОВИХ ЗАКЛАДІВ ОСВІТИ МЕТОДИКИ ФОРМУВАННЯ ЛІДЕРСЬКОЇ КОМПЕТЕНТНОСТІ МАЙБУТНІХ ОФІЦЕРІВ
}

\begin{abstract}
У статті представляються результати педагогічного дослідження щзодо обтрунтування $i$ впровадження педагогічних умов формування лідерської компетентності майбутніх офіцерів в системі професійної підготовки у вищих військових закладах освіти. У своєму дослідженні автор зосереджує увагу на індивідуалізаџї̈ професійної підготовки майбутніх офіцерів, педагогічній роботі із невеликими

групами курсантів, творчому використанні вирімення індивідуальних творчих лідерських завдань; науково-дослідній, творчій роботі курсанта; виріменні творчих проблемних лідерських ситуацій під час їх навчання шляхом впровадження методики формування лідерської компетентності.
\end{abstract}

Ключові слова: організаційні і методичні умови, педагогічні технології і методики, лідерська компетентність, квазілідерські завдання.

Постановка проблеми у загальному вигляді та іï зв'язок із важливими науковими і практичними завданнями. Будь-яке знання, що курсант отримує у вищому військовому закладі освіти (далі - ВВЗО), включається в його професійну компетентність, зокрема й лідерську, лише за умов його адаптації до індивідуальної системи цінностей. Залучення у пізнавальну активність емоційно-вольової сфери структури особистості, включення іiі емоційно-почуттєвого досвіду сприяє ефективному формуванню у майбутнього офіцера професійних знань, навичок, вмінь, професійно-значущих якостей, соціально-психологічних установок i набутого досвіду. Якщо є суб'єктивна мотивація, отримана навчальна інформація набуває не тільки смислового наповнення, але й значущості.

Тому однією з головних умов формування лідерської компетентності майбутніх офіцерів у ВВ3О $\epsilon$ поєднання процесів навчання і виховання військових лідерів. Важливо враховувати ту обставину, що виховання у системі педагогічної діяльності буде таким, що навчає тільки тоді, коли поряд із виховними цілями ставляться цілі навчальні. А навчання, у свою чергу, буде тим, що виховує тільки тоді, якщо поряд із навчальними будуть ставитися і досягатися виховні цілі. Відповідно, взаємодія компонентів навчання і виховання у ВВЗО майбутніх військових лідерів веде до формування у них певних особистісних якостей, що необхідні і важливі для лідерства.

Аналіз основних досліджень і публікацій із зазначеної проблеми. Теоретико-методологічні основи наукового розв'язання загально педагогічних проблем формування лідерства майбутніх офіцерів у ВВНЗ, як професійно важливого явища, викладено в літературі з розвитку педагогічної науки та практики в Україні. Суттєвий інтерес у цьому плані для нашого дослідження становлять праці А. М. Алексюка, В. І. Свдокимова, А. І. Зільберштейна, В. О. Онищука, В. І. Помогайба, М. Д. Ярмаченка та ін., які розробляли загальну методологію педагогіки.

Проблемами професійної освіти займалося багато відомих зарубіжних вчених-педагогів, роботи яких становлять значний інтерес для обгрунтування предмета нашого дослідження. Наприклад, щодо проблемного навчання - В. Оконь; навчання військовослужбовців - Я. Богуш; компетентнісного підходу до підготовки військових фахівців - С. Ламберт, Р. Свайн; формування лідерства військових фахівців Д. Адаір, Р. Джіннет, Г. Карфі, К. Колена, М. Мерфі, Е. Пураєр, В. Розенбах та ін.

Цікавими для нашого дослідження $\epsilon$ праці таких американських вчених, як: Д. Крендалл, Т. А. Колдіц, Д. М. Мелоун, П. Дж. Свіней, що займаються вирішенням проблеми формування лідерства в процесі професійної підготовки військових фахівців.

Великий внесок у вітчизняну військову педагогіку щодо розробки методологічних підходів підготовки військовослужбовців на основі особистісно-орієнтованої та суб'єктно-діяльнісної концепції навчання військових фахівців зробив В. В. Ягупов.

Проблема лідерства у військовому колективі розглядалась у дослідженнях вітчизняних психологів і педагогів Д. М. Коцеруби, О. Г. Романовського, Г. Г. Шевченка; О. К. Маковського - досліджували формування в курсантів якостей лідера військового колективу; А. Ю. Видая - формування лідерської спрямованості майбутнього офіцера Збройних Сил України тощо.

У своєму дослідженні О. К. Маковський [1] висунув гіпотезу, що ефективне формування у майбутніх офіцерів якостей лідера можливе у ВВЗО за таких організаційно-педагогічних умов:

1) виділення завдань формування лідерських якостей у пріоритетний напрям професійної підготовки курсантів; 
2) демонстрування викладачами і командирами підрозділів зразків лідерської поведінки у процесі навчальної та службової взаємодії з курсантами;

3) забезпечення у навчально-виховному процесі можливостей для виявлення курсантами ініціативи і самостійності, лідерської поведінки;

4) ігрове моделювання у педагогічному процесі способів виконання курсантами лідерських функцій майбутньої професійної діяльності;

5) індивідуалізація професійної підготовки курсантів на підставі діагностики та корегування їх лідерських якостей;

6) підвищення психолого-педагогічної компетентності науково-педагогічних працівників щодо формування лідерських якостей у курсантів.

Одним із вагомих результатів дослідження вченого $є$ те, що ним обгрунтовано організаційнопедагогічні умови формування лідерських якостей, з урахуванням яких було розроблено педагогічну технологію формування якостей лідера майбутніх офіцерів, основними елементами якої є: ігрова педагогічна програма формування якостей лідера військового колективу; серія тренінгових вправ; методичні рекомендації командному та викладацькому складу щодо формування якостей лідера майбутніх офіцерів.

Дослідники Ю. І. Сердюк та Д. В. Іщенко основними психолого-педагогічними умовами розвитку готовності курсантів до лідерства визначили такі:

1) включення у кваліфікаційні характеристики фахівців як професійно важливі якості офіцера вимог щодо підготовки офіцерів-лідерів;

2) розгляд готовності курсантів до лідерства як мети навчально-виховного процесу, визначення змісту навчання, тобто сукупності навчальних дисциплін на весь термін навчання, на кожен курс навчання;

3) використання в навчально-виховному процесі таких наукових принципів, як: соціальна обумовленість й науковість навчання; моделювання змісту й динаміки діяльності офіцера-лідера; активність особистості в оволодінні професійною діяльністю офіцера-лідера у навчальній діяльності військового вищого навчального закладу;

4) вибір відповідної системи педагогічних засобів, зокрема мети, змісту, методів, організаційних форм, забезпечення відповідних міжпредметних зв'язків та відносин між суб'єктами навчального процесу;

5) розробка заходів щодо підготовки викладацького складу до роботи 3 формування готовності майбутніх офіцерів-прикордонників до лідерства [2].

Окреслення невирішених питань, порушених у статті. Невирішеними питаннями в педагогічних дослідженнях залишаються обгрунтування і розробка педагогічних умов впровадження методики i педагогічних технологій, які дозволяють ефективно формувати лідерську компетентність в професійній підготовці майбутніх офіцерів.

У даній статті маємо на меті розкрити основні організаційні і методичні умови впровадження у навчально-виховний процес вищих військових закладів освіти форм і методів формування лідерської компетентності майбутніх офіцерів.

Виклад основного матеріалу 3 обгрунтуванням отриманих наукових результатів. Формалізований навчально-виховний процес без включення емоційно-почуттєвого, ціннісного контексту не здатний забезпечити на виході якісну освіту офіцера Збройних Сил України. Невдача при підготовці веде до підготовки невдачі. Як наслідок, система військової освіти не буде спроможна продукувати справжніх військових лідерів - для цього недостатньо перманентно "удосконалювати" навчальний процес у ВВЗО. Необхідно більш активно брати участь у процесі формування професійно-значущих якостей особистості і лідерських здатностей майбутнього офіцера, коли набуваються навички комунікації і міжособистісної взаємодії, чітко вибудовується індивідуальна система цінностей, молода людина визначає своє ставлення до лідерства у військовій сфері управління, проявляє активну життєву позицію і самостійність у судженнях, а також розкриває лідерський потенціал.

Ми погоджуємося 3 думкою, про те що лідерство - це відношення домінування і підпорядкування впливу і слідування цьому впливові у системі групових міжособистісних відносин. Відповідно, в широкому сенсі слова, лідерство - це один із способів організації і управління групою, що дозволяє поєднати поняття "лідер" і "керівник" i, незалежно від їх відмінностей, говорити про те, що розвиток здатностей лідера сприяє розвиткові якостей керівника. Однак, лідерство можна вважати, за визначенням С. А. Калашнікової [3: 41-42] "вищим еволюційним та якісним рівнем управління" (рис. 1).

Які ж умови успішного навчання і виховання військових лідерів найголовніші? Перш за все, щоб виховувати людину, іiі потрібно добре знати. К. К. Ушинський зазначав, що вихователь повинен знати спонукальні причини найбрудніших і найвищих діянь, історію зародження злочинних і великих думок, історію розвитку будь-якої пристрасті і всякого характеру: тоді тільки він в змозі черпати в самій природі людини засоби виховного впливу, а можливості ці величезні.

У той же час дотепер незрозуміло, чи потрібні особистості володіти специфічними (унікальними) 
якостями лідера (сила і рухливість нервових процесів, здатність до співчуття, яскраво виражені евристичні та інтелектуальні здібності і т. ін.)? Проведені дослідження показують, що наявність одних якостей і рис лідера є недостатньою для досягнення ефективного впливу, необхідні також інші, додаткові чинники. Ні якості особистості, ні особливості поведінки і ситуації, в яких приходиться діяти лідеру, самі по собі не виявляють системні джерела і механізми феномена лідерства і лідера. Як уявляється, лідером може стати людина, здатна до "підлаштування" своєї особистості або конструктивного самовизначення в інтересах досягнення цілей спільної діяльності. Тим самим лідерські якості, лідерська поведінка можуть бути розвинуті і покращені завдяки навчанню і вихованню.

Однією 3 організаційних, педагогічних умов формування лідерської компетентності майбутніх офіцерів у ВВЗО є ретельне планування і реалізація стажування (навчальної практики) курсантів старших курсів (3-4-5-го) на сержантських посадах у своїх навчальних групах або в групах молодших курсів, а також у військах на посадах командирів відділень. Додатково необхідно організувати наставництво старших курсантів над молодшими (курсами) щодо надання допомоги і передачі службового, навчального і методичного досвіду.

Отже, практичне виконання курсантами обов'язків командира відділення, заступника командира взводу (стажування на сержантських посадах у навчальних групах) дозволить:

1) виявити позитивні і негативні риси характеру і рівень лідерського потенціалу майбутнього офіцера;

2) набути первинного досвіду прояву лідерської поведінки, здійснити оцінку і самооцінку сформованості відповідних лідерських навичок і вмінь;

3) "зануритися" у майбутню діяльність командира підрозділу і "пережити" ситуації, що наближені до реальних вже під час підготовки до служби на офіцерських посадах;

4) відчути рівень відповідальності, самостійності у прийнятті рішень, довіру і надання допомоги як від старших командирів, так і від товаришів по службі тощо.

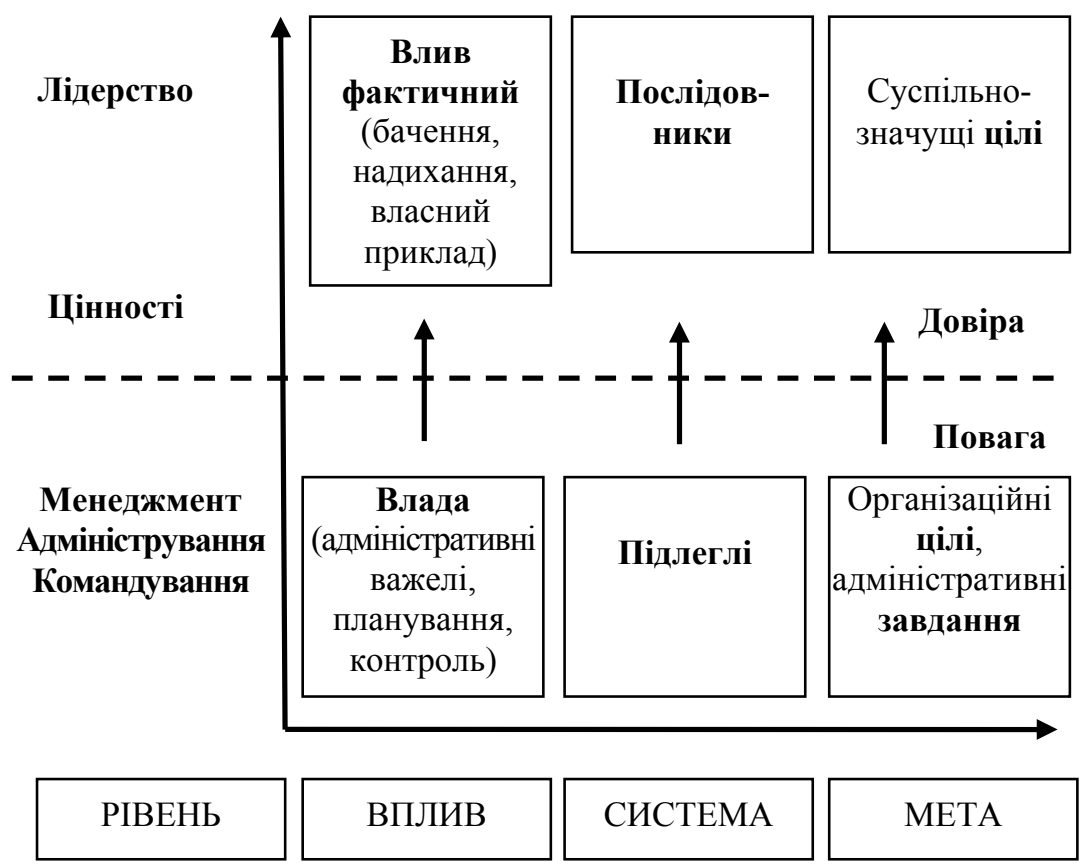

Рис. 1. Трансформація сутності управління в лідерство через еволюційні рівні [3: 43]

Крім того, процес формування лідерської компетентності майбутніх офіцерів у ВВЗО передбачає також набуття ними навичок і вмінь дотримуватися певного лідерського стилю поведінки, вимогливості і комунікації з оточуючими. Процес набуття таких поведінкових компетенцій військового лідера доцільно також організувати при стажуванні на посадах сержантів у навчальних групах. Офіцери курсової ланки, офіцери-куратори та науково-педагогічні працівники з цією метою зобов’язані моделювати у навчальновиховному процесі ВВЗО такі педагогічні умови, як:

- доцільність і законність вимог;

- персональна відповідальність за доручену справу;

- прояв довіри, контроль і перевірка якості виконання доручень (як навчальних, так і службових);

- показ особистого прикладу у добросовісному ставленні до служби і навчання, прояв дійсного авторитету серед підлеглих і колег по службі;

- справедливість і відповідність вимог з урахуванням знання особливостей співслужбовців тощо. 
На нашу думку, відмінною школою формування лідерської компетентності у майбутніх офіцерів є їх участь у підготовці, організації різноманітних виховних, культурно-освітніх, дозвільних, військовопатріотичних, спортивно-масових заходів, що систематично проводяться у ВВЗО.

Відомо, що в основі виховання лежать певні ідеї, які є наслідком розуміння того, як, в якому напрямку, з якою метою слід здійснювати виховання, на що необхідно звертати увагу і що слід використати для досягнення поставлених цілей. У найзагальнішому вигляді ці ідеї щодо формування лідерської компетентності майбутніх офіцерів у ВВЗО наступні:

1. Формування і розвиток цінностей, всебічне виховання майбутнього військового лідера має бути поставлено вище його освіти.

2. Основною турботою держави, кожного уряду є виховання та освіта нації в національному та патріотичному напрямах, особливо майбутніх військових лідерів.

3. Військове виховання настільки специфічне, що вимагає самостійного окремого обгрунтування. Тому для кращого вирішення питання військової освіти треба визнати корисним існування особливих військових освітніх закладів, де б виховувалася молодь 3 дитячого віку. Але на нашу думку, одностороннє, замкнуте військове виховання в наш час не досягне мети.

4. Особи, яким доручається моральне виховання майбутніх офіцерів, повинні, по можливості, володіти усіма видами авторитету: авторитетом переваги сильної духовної особистості, авторитетом переваги знань і авторитетом влади, тобто авторитетом особи, якій вихованці звикли підкорятися без застосування менторського впливу, а на основі партнерської взаємодії, поваги і довіри.

5. Науково-педагогічні працівники та курсові офіцери у ВВЗО несуть величезну відповідальність не тільки перед своїми вихованцями, а й перед Україною й армією - ні в одній професії людина не стає самостійно на життєвий і професійний шлях так швидко, - 3 усією їі мінливістю - у такому ранньому віці, як офіцер-випускник.

6. Завдання сучасного педагога ВВЗО велике, почесне та ідейне. Завдання тим більше ідейне і почесне, що корпорації наших військових педагогів в ім'я вищих інтересів нації і армії доводиться вести боротьбу не тільки 3 природними поганими нахилами вихованця, але й зі згубними ціннісними поглядами окремих сімейств і з сумним плином громадських інстинктів сучасності, а також 3 ворожою пропагандою.

7. Одностайність і злагоджена робота офіцерів курсової ланки і науково-педагогічних працівників - це серйозний і суттєвий крок благотворного виховного впливу на вихованців ВВЗО. Юнацтво надзвичайно чуйне до всього, що відбувається в середовищі його керівників.

8. Вищими спонуканнями здавна визнаються: релігійність - джерело моральної чистоти людини; патріотизм - безмежна любов до України, до своєї національності і до вищого служіння їі інтересам; почуття обов'язку, що виражається в покірності законам, правилам служби (дисципліни) i, взагалі, в готовності виконати прийняті на себе зобов'язання, якими б вони важкими не були; почуття гідності, честолюбство і славолюбство, любов до слави - основа більшості військових чеснот і вищих подвигів; нарешті, почуття братства (корпоративності), що народжує товариське єднання - джерело взаєморозуміння і взаємної виручки.

Визначимо основні напрями роботи науково-педагогічних працівників, командирів (начальників) щодо морального виховання майбутніх офіцерів як лідерів у ВВЗО:

- надавати курсантам знання про вимоги, що висуваються з боку суспільства до їх професійного i морального образу військового лідера;

- пояснювати соціальну значущість військової служби, її позитивні і негативні прояви;

- стимулювати потреби і створювати мотиви курсантів до морального вдосконалення;

- застосовувати виховний вплив у відповідності з досягнутим рівнем моральної зрілості курсантів;

- цілеспрямовано організовувати морально значущу діяльність курсантів, у процесі якої формується, усвідомлюється і переживається особистісний сенс моральних принципів і норм, попереджаються негативні дії і вчинки, формуються моральні почуття;

- вивчати і використовувати у виховних цілях індивідуальні особливості курсантів, результати впливу думки спільноти і здорового соціально-психологічного клімату у конкретній навчальній групі;

- використовувати духовно-моральний потенціал різноманітних громадських об'єднань (ради сержантів, ради курсантських матерів, педагогічні ради, ветеранські організації та ін.) 3 метою морального виховання майбутніх офіцерів тощо.

Процесуальну площину педагогічної діяльності науково-педагогічних працівників та офіцерів факультету i курсової ланки щодо формування необхідних морально-етичних якостей майбутніх військових лідерів нами визначено через створення певних умов у навчально-виховному процесі ВВЗО.

Необхідний рівень морально-етичного впливу на свідомість курсантів може бути забезпечений при дотриманні науково-педагогічними працівниками, командирами (начальниками) таких вимог і норм:

- усебічне врахування індивідуально-психологічних особливостей курсантів та соціальнопедагогічних явищ у навчальній групі; 
- поважне й уважне ставлення як до окремого курсанта, так і до навчальної групи в цілому, без будьяких упереджень;

- розумна вимогливість до курсантів, піклування про їх самовдосконалення, високоморальну громадянську позицію;

- витримка та врівноваженість, доброзичливість і, до певної міри, неформальність у спілкуванні 3 курсантами (партнерство), довіра, взаємоповага і тактовність;

- моральна відповідальність за взаємовідносини, що складаються між курсантами, стимулювання позитивних проявів особистості, забезпечення мотиваційної основи морально-етичного вдосконалення, підтримка всіх корисних починань;

- педагогічний оптимізм, активна життєва позиція викладача, офіцера;

- непримиренність до аморальності, особистий приклад викладача, офіцера.

Крім того, офіцерові, викладачеві ВВЗО, який формує в процесі підготовки майбутнього офіцера морально-етичні цінності майбутнього військового лідера необхідно знати, що особистість у процесі спілкування задовольняє свою вищу потребу - потребу в людяності.

Комунікативні здібності офіцера управлінської або курсової ланки, науково-педагогічні працівники регулюють міжособові відносини, що вимагає від них творчого підходу до створення різних форм спілкування з курсантами, що сприяють прояву у них таких людських якостей, як гідність, свобода, пошана, що характеризують індивідуальність. Спілкування розвиває відчуття людини, його етичні цінності, формує ідеали.

У спілкуванні проявляється ієрархія ціннісних орієнтацій особистості, характер її життєвих відносин (до себе, до інших, суспільства, служби, життя в цілому). Який би стиль спілкування не вибрав офіцер курсової ланки, науково-педагогічний працівник, йому завжди доводиться синтезувати здатність розуму і волі, етичну свідомість і поведінку, мотиви і відчуття.

Комунікативна діяльність людини складна, тому що вона пронизує всі форми його активності i навіть, на думку вчених, форми пасивності, такі, як сновидіння.

Існують різні форми спілкування, кожна з яких має свою характеристику й особливості. Мистецтво спілкування полягає в знанні характеристик рівнів, норм психогігієни спілкування і в умілому керівництві ними на практиці.

У процесі формування морально-ціннісних орієнтацій офіцерам факультету, курсу, науковопедагогічним працівникам не уникнути так званих етичних конфліктів з курсантами.

Лише ті офіцери, викладачі, які своїми конкретними практичними діями і вчинками зближують дійсність 3 етичним ідеалом, здатні ушляхетнювати мікросередовище i розумно вирішувати конфліктогенні ситуації. Формула їх поведінки: оцінка ситуації - рішення - дія. У даному випадку мається на увазі дія, за своєю значущістю рівноцінна вчинку. Ми розрізняємо поняття "дія" і "вчинок". Вчинок - звеличення, підтвердження або повалення цінностей, переосмислення життєво значущого. Вчинок - категорія етично-ціннісного змісту. Він $є$ сукупністю етичних відносин, які виражають його суть.

Мотив, мета, засоби, дії, наслідки дають нам уявлення про конкретний вчинок, а серія вчинків дає нам уявлення про етичну діяльність особи, іiі активну або пасивну позиції. Здатність перетворювати обставини в ім'я етичних цілей, уміння ухвалювати рішення і вибирати засоби відповідно до етичної необхідності свідчать про те, що майбутній офіцер як військовий лідер у розмаїтті ситуацій повинний свідомо визначити лінію поведінки, співвідносячи моральний вибір 3 життєвими обставинами, продемонструвавши при цьому гуманність, принциповість, протидію аморальному.

Основні положення нашого наукового дослідження можуть бути покладені в основу впровадження у систему професійної підготовки майбутніх офіцерів у ВВЗО основних ідей і положень нашої концепції, увійти до підручників, навчальних, навчально-методичних i методичних посібників 3 підготовки військових лідерів як офіцерського, так і сержантського складу.

Напрямами впровадження результатів нашого дослідження у військову практику вважаємо:

1) розроблення нормативно-методичної документації щодо організації професійної підготовки майбутніх офіцерів у ВВЗО на основі визначених у дослідженні основних ідей і положень формування лідерської компетентності на основі суб'єктно-діяльнісного та функціонально-компетентнісного підходів;

2) уточнення цілей підготовки майбутніх офіцерів до лідерства при виконанні обов'язків на первинних посадах у військах;

3) застосування науково-педагогічними працівниками таких педагогічних технологій і методик підготовки майбутніх військових лідерів, як: консультування, метод проектів, моделювання, діяльнісне навчання, емпіричне навчання, тренінг, коучинг тощо; впровадження офіцерами курсової ланки та курсантами в систему підготовки аналізу конкретних лідерських ситуацій (вирішення квазілідерських завдань), неформального аналізу проведених дій у навчально-виховному процесі ВВЗО, що дозволить поєднати розгалужені на сьогоднішній день психолого-педагогічні та військово-спеціальні дисципліни їх 
лідерської підготовки у систему;

4) поліпшення інформаційно-методичного забезпечення лідерської підготовки курсантів у навчально-виховному процесі ВВЗО та методичного супроводу подальшої служби у військах з боку наставників $з$ числа викладачів;

5) створення i підтримання у ВВЗО позитивної морально-психологічної атмосфери, яка найбільшою мірою сприяє розвитку активності, самостійності та відповідальності курсантів за свою підготовку до виконання професійних функцій військового лідера;

6) зосередження на індивідуалізації навчання, педагогічній роботі із невеликими групами курсантів, широким використанням вирішення індивідуальних творчих завдань, самостійного пошуку інформації, вирішення проблемних ситуацій під час навчання тощо.

Більш докладно проаналізуємо ці основні напрями.

При розробці нормативно-методичної документації щодо організації підготовки майбутніх офіцерів як військових лідерів на основі ідей і положень суб'єктно-діяльнісного та компетентнісного підходів, визначенні таксономії цілей методики формування у них лідерської компетентності та обгрунтуванні ії змісту і послідовності, необхідно враховувати структуру модульної системи організації їх підготовки. Це вимагає передбачення:

на орієнтовно-мотивачійному етапі: визначення та постановки навчальної, виховної та розвивальної цілей навчального модуля та окремо даного етапу; презентацію науково-педагогічними працівниками структурно-часової моделі навчального модуля; розкриття перспектив подальшої навчальної діяльності курсантів і можливостей застосування поведінкових компетенцій у сфері лідерства; формування позитивної установки, мотивації та стимулювання навчальної діяльності курсантів; подання навчального матеріалу у вигляді конкретної лідерської проблеми з військової практики; ознайомлення курсантів 3 категоріально-понятійним апаратом навчального матеріалу щодо лідерства;

на змістовно-пошуковому етапі: актуалізації загальнонаукових, військово-професійних й поведінкових компетенцій лідерства; ознайомлення їх з навчальною проблемною ситуацією лідерського спрямування; створення викладачами проблемних професійних ситуацій, які потребують від курсанта лідерської поведінки; постановка курсантам індивідуальних творчих завдань щодо прояву лідерства та організація пошукової діяльності навчальних підгруп з розв'язання проблемної ситуації; вирішення курсантами квазілідерських завдань 3 метою створення індивідуальної технології лідерства та ії презентації (показу);

на допоміжному етапі: проведення фронтальних та індивідуальних бесід із курсантами з основних питань навчального матеріалу; навчальне тестування; організація самостійної роботи курсантів 3 розв'язання квазілідерських завдань; взаємодопомога, взаємо- і самоконтроль та перевірка результатів навчальної діяльності; консультування, інструктування та надання допомоги курсантам;

на етапі узагальнення поведінкових компетенщій військового лідера, формування власного стилю лідерства: організація навчальної діяльності курсантів щодо систематизації вивченого матеріалу; підготовка різноманітних матеріалів до звіту; проведення індивідуального та колективного консультування; написання наукових та інших науково-дослідних робіт; участь у наукових заходах; прийняття рішень на рівні курсантського підрозділу (навчальної групи), курсу;

на адаптивно-перетворювальному етапі: повторення основних теоретичних положень навчального матеріалу щодо лідерства військовослужбовців та основних методик розв'язання квазілідерських завдань; самостійне і групове розв'язання квазілідерських завдань; застосування отриманих поведінкових компетенцій лідера у нестандартних умовах; створення і презентація індивідуальної технології (методики, стилю) лідерської поведінки; внесення змін та нововведень до власного стилю лідерства, надання консультацій і допомоги іншим курсантам; взаємо- і самоконтроль та самоперевірка результатів власної лідерської діяльності;

на етапі контролювання та рефлексування поведінкових компетенцій лідерства: проведення проміжного та підсумкового видів контролю за рівнем оволодіння курсантами системою лідерських компетенцій, практичних навичок і вмінь; усвідомлення курсантами результатів підсумкового контролю за рівнем своїх лідерських ЗНУ і рівня сформованості поведінкових компетенцій та їх об’єктивна рефлексія.

У прочесі визначення таксономії иілей формування лідерської компетентності майбутніх офічерів у ВВНЗ необхідно здійснити такі заходи:

- на етапі професійного добору, крім психофізіологічних особливостей, діагностувати мотивацію майбутньої навчальної діяльності та лідерства, творче ставлення кандидатів до власної підготовки у ВВЗО як військових лідерів, а також з'ясувати їхні лідерські якості тощо;

- на орієнтовно-мотиваційному етапі підготовки курсантів до лідерства основну увагу зосередити на формуванні у них позитивного ставлення до навчальної та майбутньої лідерської діяльності, вивченні психолого-педагогічних і військово-спеціальних дисциплін;

- на змістовно-пошуковому етапі особливу увагу слід звернути на набуття практичних навичок $\mathrm{i}$ 
вмінь лідерства майбутніми офіцерами та формування у них основ творчого стилю лідерства засобами і методиками навчальних дисциплін, що викладаються на кафедрах ВВЗО; паралельно слід звернути увагу на їх управлінську підготовку як командирів підрозділів;

- змістом наступного етапу є підготовка курсових та науково-дослідних робіт, творчих завдань і доручень за професійно-орієнтованими дисциплінами, військове стажування (навчальна практика); участь у командно-штабних навчаннях тощо;

- на адаптивно-трансформаційному етапі головні зусилля зосередити на підготовці майбутніх офіцерів до формування творчої методики та стилю лідерства під час виконання обов'язків на первинній посаді;

- на системно-моделюючому етапі проводити військове стажування (практику), командно-штабні навчання, включення результатів вирішення квазілідерських завдань у повсякденну навчальну i позанавчальну діяльність курсантів.

На цьому етапі у процесі вивчення соціально-гуманітарних і професійно-орієнтованих (військовоспеціальних) дисциплін доречно проводити заняття методами аналізу конкретних ситуацій (case-study), які поділені на функціональні блоки. Тобто, наприклад, у 6-8-му семестрах у ВВЗО необхідно спланувати заняття таким чином, щоб курсанти постійно виявляли на них свій лідерський потенціал. Метою застосування цього методу $\epsilon$ накопичення курсантом власного практичного досвіду щодо вирішення проблемних службових (навчально-бойових) ситуацій і створення індивідуальної технології (методики, стилю) лідерства, доведення своїх професійних дій i рішень до рівня лідерської компетентності;

- завдання контрольно-рефлексивного етапу формування лідерської компетентності слід розподілити послідовно, у процесі всієї професійної підготовки майбутніх офіцерів, які слід розташувати за семестрами, основними видами їх професійної та фахової підготовки. Безперечно, таким основним видом перевірки $з$ боку держави і 3 боку самого офіцера $є$ державний екзамен та військове стажування (навчальна практика) на первинній посаді у військах [4].

Висновки та перспективи подальшого дослідження проблеми. Такий організаційний і методичний підхід до організації професійної підготовки курсанта, на нашу думку, дозволить йому оптимально визначити ціль кожного навчального модуля 3 професійно-орієнтованих (військово-професійних) дисциплін, інтегрувати поведінкові компетенції лідерства зі всіх навчальних дисциплін, а найголовніше курсант спроможний чітко визначитися щодо навчальної та майбутньої лідерської діяльності, творчо ставитися до набуття власного стилю лідерства ще під час навчання у ВВЗО.

Постає необхідність зосередження уваги на індивідуалізації професійної підготовки майбутніх офіцерів, педагогічній роботі із невеликими групами курсантів, творчому використанні вирішення індивідуальних творчих лідерських завдань; науково-дослідній, творчій роботі курсанта; вирішенні творчих проблемних лідерських ситуацій під час їх навчання у ВВЗО шляхом впровадження методики формування у них лідерської компетентності.

На нашу думку, використання передового досвіду комплексного впровадження суб'єктнодіяльнісного та компетентнісного підходів у підготовку майбутніх військових фахівців дозволить суттєво покращити управлінську і лідерську підготовку майбутніх офіцерів Збройних Сил України.

Методика формування лідерської компетентності майбутніх офіцерів Збройних Сил України, створена нами за новітньою парадигмою навчання, - це тільки початок впровадження ії положень у систему вищої військової освіти. Такий напрям діяльності має спиратися не тільки на зусилля окремих педагогів-новаторів, а грунтуватися на переконаннях усього педагогічного колективу ВВЗО і здобутого офіцерами-випускниками бойового досвіду.

Напрямами подальшого дослідження проблем вдосконалення лідерської підготовки майбутніх офіцерів у ВВЗО можуть бути:

- обгрунтування, розробка і впровадження інноваційних педагогічних технологій лідерської підготовки офіцерів на основі сучасних концепцій ціннісного і трансформаційного лідерства;

- забезпечення творчого сприйняття та усвідомлення науково-педагогічними працівниками сутності нових педагогічних технологій і методик на основі суб'єктно-діяльнісного і компетентнісного підходів у професійній підготовці офіцерів;

- створення спільної асоціації викладачів для підготовки військових лідерів у педагогічній системі вищих закладів освіти інших військових формувань та авторський контроль з ії боку правильності трактування та ефективності реалізації їі розробок;

- цілеспрямована організація науково-методичної роботи у ВВЗО, що передбачає організацію участі всіх науково-педагогічних працівників у дослідно-експериментальній роботі з проблем військової лідерології та активне залучення до іiї проведення курсантів ВВЗО;

- проведення науково-дослідних робіт з проблеми підготовки військових керівників на основі науково обгрунтованих концепцій лідерства, що реалізовані в підготовці цивільних фахівців тощо. 


\section{СПИСОК ВИКОРИСТАНИХ ДЖЕРЕЛ ТА ЛІТЕРАТУРИ}

1. Маковський О. К. Формування лідерських якостей майбутніх офіцерів [Текст] : автореф. дис. ... канд. пед. наук : спец. : 20.02.02 / Маковський Олег Казимирович ; Національна академія Прикордонних військ України ім. Богдана Хмельницького. - Хмельницький, 2002. - 18 с.

2. Сердюк Ю. І. Педагогічні умови формування лідерських якостей курсантів ВВНЗ у процесі навчання загальновійськових дисциплін / Ю. І. Сердюк, Д. В. Іщенко // Зб. наук. праць НАДПС України. Серія : Педагогічні і психологічні науки. - 2010. - № 56. - С. 123-126.

3. Калашнікова С. А. Освітня парадигма професіоналізації управління на засадах лідерства [Текст] : [монографія] / С. А. Калашнікова. - К. : Київ. ун-т ім. Б. Грінченка, 2010. - 379 с.

4. Бойко О. В. Теоретико-методичні проблеми формування лідерської компетентності майбутніх офіцерів Збройних Сил України : [монографія] / О. В. Бойко. - Львів : АСВ, 2014. - 543 с.

\section{REFERENCES (TRANSLATED \& TRANSLITERATED)}

1. Makovs'ky O. K. Formuvannia liders'kykh yakostei maybutnikh ofitseriv [Formation of Leadership Qualities of Future Officers] [Tekst] : avtoref. dys. ... kand. ped. nauk: spets. 20.02.02 / Makovs'ky Oleh Kazymyrovych ; Natsional'na akademiia Prykordonnykh viis'k Ukrainy im. Bohdana Khmel'nyts'koho. - Khmel'nyts'kyi, 2002. $18 \mathrm{~s}$.

2. Serdiuk Yu. I. Pedahohichni umovy formuvannya liders'kykh yakostey kursantiv VVNZ u protsesi navchannia zahal'noviis'kovykh dystsyplin [Pedagogical Conditions of Formation of Leadership Qualities of Cadets of Higher Military Educational Institutions in the Process of Teaching of Joint Military Disciplines] / Yu. I. Serdiuk, D. V. Ishchenko // Zb. nauk. prats' NADPS Ukrainy. Seriia : Pedahohichni i psykholohichni nauky. - 2010. - № 56. - S. 123-126.

3. Kalashnikova S. A. Osvitnia paradyhma profesionalizatsii upravlinnia na zasadakh liderstva [Educational Paradigm of Management Professionalism on the Basis of Leadership] [Tekst] : [monohrafiia] / S. A. Kalashnikova. - K. : Kyyiv. un-t im. B. Hrinchenka, 2010. - 379 s.

4. Boyko O. V. Teoretyko-metodychni problemy formuvannia liders'koi kompetentnosti maybutnikh ofitseriv Zbroynykh Syl Ukrainy [Theoretical and Methodical Problems of Forming the Leadership Competency of Future Officers of the Armed Forces of Ukraine] : [monohrafiia] / O. V. Boyko. - L'viv : ASV, 2014. - 543 s.

Бойко О. В. Педагогические условия внедрения в учебно-воспитательный процесс высших военных заведений образования методики формирования лидерской компетентности будущих офицеров.

В статье представляются результаты педагогического исследования по обоснованию и внедрению педагогических условий формирования лидерской компетентности будущих офицеров в системе профессиональной подготовки в выстих военных учебных заведениях. В своем исследовании автор сосредоточивает внимание на индивидуализации профессиональной подготовки будущих офицеров, педагогической работе с небольшими группами курсантов, творческом использовании решения индивидуальных творческих лидерских задач; научно-исследовательской, творческой работе курсанта; решении творческих проблемных лидерских ситуаций во время их обучения путем внедрения методики формирования лидерской компетентности.

Ключевые слова: организациионные и методические условия, педагогические технологии и методики, лидерская компетентность, квазилидерские задачи.

\section{Boyko O. V. Pedagogical Conditions of Introduction into the Educational Process of Higher Military Educational Institutions of the Formation of Leadership Competences of Future Officers.}

Any knowledge that a student receives in a higher military educational institution is included in his professional competence, including leadership, only if he adapts to an individual value system. Involvement in the cognitive activity of the emotional-volitional sphere of the personality structure, including its emotional and sensory

experience, contributes to the effective formation of a future officer of professional knowledge, skills, professional qualities, socio-psychological settings and acquired experience.

Therefore, one of the main conditions for forming the leadership competency of future officers in the Secondary

School is the combination of the processes of training and education of military leaders.

Having analyzed the modern scientific approaches in the article the following basic organizational and methodical conditions of the process of forming the leadership competence of future officers in higher military educational institutions are defined: careful planning and implementation of internship (training practice) of senior cadets in sergeant positions in their training groups or in groups of junior courses, as well as in the troops in the posts of commanders of units; acquiring their skills and abilities to adhere to a certain leadership

style of behavior, demanding with others; the necessary level of moral and ethical influence on the

consciousness of cadets can be provided with the observance of scientific and pedagogical workers, commanders (heads) of moral requirements and norms; on the basis of ideas and provisions of subject-activity and competence approaches, determination of the taxonomy of the goals of the methodology of forming their 
leadership competence and substantiation of its content and consistency, it is necessary to take into account the structure of the modular system for organizing their preparation. It is spoken in detail about the individualization of the training of future officers, pedagogical work with small groups of cadets, creative use of solving individual creative leadership tasks; scientific research, creative work of the cadet; solving creative problem leadership situations during their training in higher military educational institutions by implementing a methodology for forming their leadership competencies.

Key words: organizational and methodical conditions, pedagogical technologies and methods, leadership competence, quasi-leadership tasks. 